\title{
Estimating the value of forests for provisioning non-timber forest products to market: concepts, approaches, and case studies
}

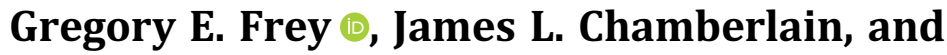 \\ John Paul Schmidt
}

\begin{abstract}
We discuss the process of estimating the ecosystem service value (ESV) for provisioning of non-timber forest products (NTFPs) to market, with a focus on the United States. NTFPs are harvested throughout the U.S. for numerous purposes, and those sold in market contribute significantly to household and local economies. While estimates of ESV can aid decision-making related to conservation and management, NTFPs have been generally neglected. We discuss challenges and approaches for prioritizing valuation, quantifying production, measuring costs and benefits, and finding data sources. Many NTFP markets are informal, and market players may have an interest in withholding information. Data about geographic and temporal distribution, production cost, quantity harvested, and price may therefore be limited. In two case studies, we explore the nuances of estimating ESV of forests for medicinal products.
\end{abstract}

Key Words: Derived demand, Ecosystem service valuation, Markets, Non-timber forest products, Provisioning

\section{Introduction}

Forests provide many tangible goods for human use. "Provisioning" of these goods is one of four categories of ecosystem service (ES) (Millennium Ecosystem Assessment 2005). Non-timber forest products (NTFPs) are a general category of goods provisioned by forests, which include food, medicine, decorations, landscaping, and arts and crafts (Chamberlain, Bush, and Hammett 1998; Chamberlain, Emery, and Patel-Weynand 2018).

Gregory E. Frey, U.S. Department of Agriculture Forest Service, Southern Research Station, Research Triangle Park, NC, USA. James L. Chamberlain, U.S. Department of Agriculture Forest Service, Southern Research Station, Blacksburg, VA, USA. John Paul Schmidt, University of Georgia, Odum School of Ecology, Athens, GA, USA. Correspondence: P.O. Box 12254, Research Triangle Park, NC 27709, Email: gregory.e.frey@usda.gov; (919) 549-4025.

This paper was prepared for the USDA Workshop "Applications and Potential of Ecosystem Services Valuation within USDA - Advancing the Science," Washington, DC, April 23-24, 2019, and for consideration for publication in Agricultural and Resource Economics Review.

Agricultural and Resource Economics Review 49/1 (April 2020) 91-116

(C) The Author(s) 2019. This is an Open Access article, distributed under the terms of the Creative

Commons Attribution licence (http://creativecommons.org/licenses/by/4.0/), which permits unrestricted re-use, distribution, and reproduction in any medium, provided the original work is 
NTFPs are harvested from private and public forests throughout the United States (Chamberlain, Emery, and Patel-Weynand 2018; Jones, McLain, and Lynch 2004), provide significant economic benefits to harvesters and related enterprises (Alexander, McLain, and Blatner 2001; Alexander, Oswalt, and Emery 2011; Chamberlain, Teets, and Kruger 2018), and are collected for personal as well as cultural purposes (Cordell et al. 2012; Robbins, Emery, and Rice 2008). Perhaps one-quarter of the U.S. population harvests NTFPs, a portion of which is for non-market purposes such as home consumption, and a portion of which is for sale in formal and informal markets (Bailey 1999; Butler 2008; Butler et al. 2016b; Cordell and Tarrant 2002; Emery et al. 2003; Jones, McLain, and Lynch 2004; Robbins, Emery, and Rice 2008).

Despite manifold uses and widespread extraction, NTFPs are generally overlooked in forest management. Appropriate valuation can help decisionmakers understand the potential impact of forest management on the welfare of surrounding communities. Lack of publicly available data, informality, secrecy, and other interrelated factors make integrating market-based NTFPs into forest valuations particularly challenging.

Sound estimates of ES values (ESVs), including how they may vary in space and time, are important for public regulatory and land management agencies that must make informed decisions as to alternative land uses or identify the most important forests for specific uses (Sills, Simpson, and Mercer 2017). Conservation-oriented organizations can identify and direct funding to areas with high conservation value, private landowners may identify market opportunities, and social welfare and emergency response organizations can understand how ecosystem changes affect community livelihoods (Frey et al. 2018; Sills, Simpson, and Mercer 2017). To do this, ESVs must be linked to actual or potential changes in forest access, land use, or land management that are "marginal," i.e. small, relative to the total forest cover in a region (Sills, Simpson, and Mercer 2017).

We describe concepts and approaches for estimating the marginal ESV that forests generate by provisioning NTFPs to markets. Although we recognize that non-market values, including subsistence, cultural, spiritual, and recreational uses, are important to communities that practice NTFP harvesting, we focus here on approaches and challenges in estimating ESV for market-oriented NTFPs. As such, we outline steps for identifying which NTFPs may be appropriate for ESV estimation, quantifying production, measuring costs and benefits, and finding data sources. We then explore these methods with simple case studies.

\section{Background}

\section{Definition and Classification}

While the definition of "non-timber forest product" can vary, most literature on NTFPs in the United States focuses on specific plants or fungi that grow in 
forests. NTFPs do not include "timber," that is, wood utilized at industrial scales or sold in commodity markets, but they do include firewood and wood for artisanal purposes (Belcher 2003; Chamberlain, Emery, and Patel-Weynand 2018). Most literature on NTFPs in the United States does not include animal wildlife, which typically receives separate treatment in forest management and scientific literature.

Five market "segments" define the NTFP sector (Chamberlain et al. 2018): edible products, medicinal and dietary supplements, decorative products, landscaping inputs, and supplies to arts and crafts. Examples of each segment illustrate the diversity of products and markets. Fruits, berries, nuts, sap, fern fronds, tubers and bulbs are edible products. Each year, sales of maple (Acer spp.) syrup contribute more than $\$ 100$ million to the U.S. economy (Farrell and Chabot 2012). Thousands of $\mathrm{kg}$ of ramps (Allium tricoccum), a native forest onion, are harvested each year for the expanding foraged food market (Baumflek 2016). The medicinal and dietary supplement segment of the NTFP industry depends on large quantities of plant materials harvested from forests for their therapeutic values. Extract of Pacific yew (Taxus brevifolia) bark was found in the early 1990s to be effective for treating ovarian cancer (Chamberlain, Bush, and Hammett 1998). Forest plants and their parts are sold to the decorative segment as greenery in floral arrangements or as the main component of fresh and dried ornaments. In 1995, the United States exported more than $\$ 14$ million in forest-harvested mosses and lichens, most of which originated from Appalachia and the Pacific Northwest (Goldberg 1996). Live forest plants are also collected for the landscaping industry. At one time, seedlings of Fraser fir (Abies fraseri), endemic to the Southern Appalachians, were "pulled" from the forest floor for transplanting to Christmas tree farms. Collection of forest understory wildflowers for horticultural sales is a cottage industry in parts of the eastern United States (Cullina 2000). The number of NTFPs used for arts and crafts is limited only by the imagination of the artisan (Chamberlain et al. 2018, p. 17). In general, though, NTFP extraction and sale for markets has been little studied relative to other forest goods and services, and the economic importance of these natural resources have, therefore, been underappreciated.

\section{Methods of Production and Sale}

Typically, NTFPs are sourced through two types of production methods. In traditional "wild harvesting," people forage the products from forests, with few inputs except for their time, transport, and minor incidentals such as a digging tool. "Forest farming," by contrast, is the cultivation of forests to produce NTFPs (Chamberlain et al. 2018). Several methods of forest farming are generally accepted (Chamberlain et al. 2009). The "wild-simulated" forest farming system includes only limited site preparation and planting, whereas a "woods cultivated" forest farming system is more intensive, potentially incorporating tillage and soil amendments, and "woods grown" forest farming 
methods rely on more inputs and maintenance. The method of production clearly has direct implications for production costs, and thus the valuation of the provisioning ES.

The level of market formality and the method of sale also have implications for ES valuation. In a first case, the landowner and harvester may be one and the same. Second, the harvester may access sites without compensating the landowner (or indeed, in some cases, without the landowner's knowledge or permission). In this case, the first point of sale may be between harvester and dealer. Third, the harvester may compensate the landowner, but outside competitive markets. This may be particularly true for harvest permits on federal lands, such as the National Forests. Fourth, commercial harvesters may directly pay a landowner for access in a competitive marketplace, as seems to be true in certain instances for saw palmetto (Serenoa repens) in Florida, and pine (Pinus spp.) straw in Georgia. Fifth, the harvesters may be employees or contractors of a larger company and may be paid either per hour or per volume of product collected. Lastly, in many cases which are important for future work but not considered in this manuscript, no market transaction takes place at all. Rather, the product is directly consumed by the harvester or given to friends and family (Frey et al. 2018).

\section{Conceptual Model}

Many users directly harvest NTFPs for personal subsistence, recreational, cultural, or spiritual value rather than for commercial sale. In these cases, parallels to recreation demand are clear, and traditional revealed or stated preference non-market valuation methods can be applied. The travel cost method, in particular, has been used for NTFP ES valuation (e.g., Markstrom and Donnelly 1988; Starbuck et al. 2004). While important tools, such methods are not the focus of this study.

\section{DERIVED DEMAND}

The demand for a market-based NTFP provisioning service is a "derived demand," in the sense that it is an input to the production of a good for sale (Flaaten 2011, p. 31; McConnell and Bockstael 2005). We focus here on how best to estimate the provisioning ESV at the margin, which can be described as the resource quasi-rent $(\rho)$ from the natural resource to the human owner of the service (Freeman 2003; Kronenberg and Hubacek 2013; McConnell and Bockstael 2005):

$$
\rho=R-V C=[p \cdot q(l, k, e)]-[w \cdot l+v \cdot k]
$$

where

$\rho$ is the resource quasi-rent, or ESV, equal to revenue $(R)$ minus variable costs of production

$(V C) . R$ is equal to price $(p)$ times quantity $(q)$. 
$q(l, k, e)$ is the production function, which maps quantity harvested as a function of the inputs labor $(I)$, capital $(k)$, and the ecosystem service $(e)$.

$w$ and $v$ are input prices.

To estimate the value of non-marginal changes of the ES, the production function $q(\cdot)$ must be known at all production levels and for all producers. Further, if the change in the ES ultimately induces a change in the price $(p)$ of the consumer good, then, to fully estimate the changes in welfare, understanding the demand function for end-use consumer goods will be necessary (Freeman 2003; McConnell and Bockstael 2005). In practical terms and at the marginal level, the resource quasi-rent or provisioning ESV may be thought of as that portion of product value that is owed to ecosystem function, or the "residual value" after factoring out the value added through human labor and capital (Smith, Crone, and Alexander 2010).

Access to a resource affects who can harvest and how much they can take. In the extreme case, open access resources allow any harvester to take as much as desired, as appears to be the case for certain marine fisheries (Gordon 1954; Flaaten 2011), and, arguably, in a de facto sense for some NTFPs, when access is difficult to control and enforce (Bulte and Engel 2006; Frey, Chamberlain, and Prestemon 2018). In such situations, economic theory holds that economic overproduction ${ }^{1}$ will drive resource quasi-rent to zero (Flaaten 2011). If the landowner can control access, a harvest level lower than the open access equilibrium can be enforced, generating resource quasirents.

\section{NET PRESENT VALUE}

We define provisioning ESVs (resource quasi-rents/residual values) in terms of dollars per unit of area by forest type-perhaps a bit of sleight of hand, as the area of forest is not the service itself, yet is a reasonable simplification for the purposes of use in forest management choices. In the simplest case, if a price is paid directly from the harvester to the landowner per unit area of forest accessed, then the contract price is equal to $R$ (equation 1 ). If the landowner has no establishment or management costs (the case for a wild-harvested product), then the price per unit area of the contract is equal to the provisioning $\mathrm{ES}\left(\rho_{t}\right)$ for a given year $t$ :

$$
\rho_{t}=R_{t}
$$

However, the situation is usually not so simple with NTFPs. In many cases, the first point of sale is not the harvester who pays a landowner per unit area for

\footnotetext{
1 Economic overproduction does not necessarily imply biological or ecological overharvest. Economic overproduction means profits are not maximized, whereas biological overharvest means yields are not maximized (Flaaten 2011; Gordon 1954).
} 
the right to access and harvest a product in the forest, but rather the harvester receiving payment from a dealer per unit of product. In some cases, permit fees are not set in a competitive market ${ }^{2}$ and may not reflect the true ESV. With such a non-market-based permit, or when no fee is paid to the landowner, the analyst should use the first point of sale $\left(P_{1}\right)$ in the competitive marketplace for valuation, taking into account that the harvester may have added value to the product through harvesting, transacting (transporting, marketing, selling), and possibly processing (e.g., cleaning, drying) the product. These human costs must be factored out to accurately estimate residual price $\left(P_{O}\right)$, which is the shadow price of the product in the woods:

$$
\begin{gathered}
P_{0}=P_{1}-(H C+T C+P C) \\
\rho_{t}=R_{t}=\left(P_{1, t}-\left(H C_{t}+T C_{t}+P C_{t}\right)\right) \cdot Q_{t}
\end{gathered}
$$

where

$P_{1}$ is the market price per unit of product at the first point of sale,

$P_{0}$ is the residual or shadow price per unit of product in the woods,

$H C$ and $T C$ are the harvesting and transaction costs per unit of product, including time traveling, collecting, marketing, and selling the product, plus fuel for transportation, depreciation of equipment, vehicles, and other factors,

$P C$ is the processing cost per unit of product of value-adding activities taking place before the first point of sale, including cleaning, drying, and

$Q_{t}$ is the quantity of NTFP produced in year $t$ on a marginal unit of forestland of a given forest type and ownership class.

Forest farming and managing natural populations may incur costs associated with establishment and management, which occur before harvest. These are variable costs but are usually associated with costs per unit of land area rather than costs per unit of product:

$$
\rho=R_{0}-V C=\left[\left(P_{1}-(H C+T C+P C)\right) \cdot Q\right]-[E C+M C]
$$

where $E C$ and $M C$ are establishment and management costs. However, because establishment and management costs occur many months or even years before harvest, analysis should consider the opportunity cost of time by discounting future values relative to present ones. The quasi-rent, or residual value, over a finite period $T$, considering the opportunity cost of time, is given by net present value $(N P V)$, which can be converted to the soil expectation value

\footnotetext{
2 Large landowners may have some level of monopoly power or may have limited information
} about market prices and costs. 
$(S E V)$ for an infinite time horizon or the equivalent annual income (EAI) (Alexander et al. 2002; Cubbage et al. 2015):

$$
\begin{gathered}
\rho_{T}=N P V=\sum_{t=1}^{T} \frac{R_{t}-C_{t}}{(1+\delta)^{t}} \\
=\sum_{t=1}^{T} \frac{\left[\left(P_{1, t}-\left(H C_{t}+T C_{t}+P C_{t}\right)\right) \cdot Q_{t}\right]-\left[E C_{t}+M C_{t}\right]}{(1+\delta)^{t}} \\
\rho_{\infty}=S E V=N P V+\frac{N P V}{(1+\delta)^{T}-1} \\
\rho_{t}=E A I=S E V \cdot \delta
\end{gathered}
$$

where

$N P V$ is the per unit area net present value over the finite "rotation" period $T$, on forestland of a given forest type and ownership class, and

$\delta$ is the discount rate.

\section{GEOSPATIAL VARIATION}

The harvestable quantity of a product is not constant over space but varies according to population characteristics and site conditions. These differences are critical in marginal valuation since site production varies. Some sites (i) will support more harvest $(Q)$ than others as:

$$
Q_{t, i}=q\left(H_{i}, Q_{t-p, i}\right)
$$

where $H$ is a vector of habitat characteristics affecting growth and yield of the plant, and $Q_{t-p}$ is harvest in a past period, $t-p$.

Furthermore, harvest and transaction costs (HC and TC) vary based on numerous factors as:

$$
\begin{gathered}
T C_{i}=\operatorname{tc}\left(D_{i}\right) \\
H C_{i}=h c\left(G_{i}, S, Q_{i}\right)
\end{gathered}
$$

where

$D_{i}$ is a vector of variables representing distance from market or population center from access point and distance and terrain from access point to harvest site.

$G$ is a vector of variables representing the difficulty of the topography and terrain at the harvest site,

$S$ is a vector of variables representing species characteristics affecting the difficulty of harvest, and 
These functions must be defined and integrated into the relevant equation (4-6), for a given species over multiple sites.

INTRA-MARGINAL RENTS: PRODUCER EXPERTISE AND HARVEST COST

A given forest area may have multiple NTFP harvesters, each with different price structures. Total harvest effort increases with the addition of more harvesters to an area. In this case, harvesters with lower costs achieve higher "intra-marginal" rents, which are distinct from the resource quasi-rents (Coglan and Pascoe 1999; Flaaten 2011, pp. 107-112).

Consider ecological knowledge, recognized as a valuable input in the sustainable production and harvest of NTFPs and the conservation of the natural resources (Ballard and Huntsinger 2006; Lake et al. 2018; Hummel and Lake 2015; Watson et al. 2018). Many aspects of ecological knowledge can be difficult to categorize and quantify, but one example is knowledge of the location of a plant population that could be harvested. A "perfectly knowledgeable" harvester would park at the closest forest access point and walk directly to the plant population to minimize time and cost. A "perfectly unknowledgeable" harvester would wander the forest searching, wasting valuable time. Ecological knowledge itself thus creates value, attributable in this case to the harvester, not to the ecosystem.

More generally, the intra-marginal rent due to lower costs of production may be attributed to the lower-cost harvester, and the resource quasi-rent attributed to any additional difference between price (average revenue) and production costs of the highest-cost producer participating in the market (Coglan and Pascoe 1999; Flaaten 2011, pp. 107-112). In equations (4-6), the relevant costs per unit product are the costs of the highest-cost producer, but the quantity is the total quantity harvested by all producers.

\section{Challenges in Valuation}

Several related challenges lead to difficulties obtaining data and applying research at broader spatial and temporal scales.

\section{LACK OF DATA FROM OFFICIAL SOURCES}

Sources of data on NTFP harvest and transactions are frequently lacking. NTFPs are restricted in geographic extent and quantity demanded, compared to commodities like timber. Therefore, NTFPs are often considered minor in economic importance, so less emphasis is put on collecting the data needed to estimate their ESV. Lack of perceived need for data reduces the incentive of government institutions like the National Agricultural Statistics Service (NASS) or for-profit services to collect market-related data. Exceptions exist for well-known NTFPs with large regional producer bases and long histories (e.g., maple syrup, wild blueberries [Vaccinium spp.]), which are tracked by NASS. American ginseng (Panax quinquefolius) is an exception to the ruleharvest volumes are tracked because it is considered vulnerable to 
overharvest and regulated by international treaty (Fish and Wildlife Service 2015).

\section{DIFFICULTY OBTAINING INFORMATION FROM MARKET PLAYERS}

For the many NTFP markets that are informal with few transaction records, gathering price and quantity data is particularly challenging (McLain, Alexander, and Jones 2008). Harvesters are many, dispersed, and challenging to contact. Furthermore, there appears to be a lack of trust among NTFP market players toward inquiring outsiders (Burkhart 2011; Greenfield and Davis 2003). Harvesters have an economic interest in keeping harvest locations, methods, quantities, and prices secret, and may also wish to avoid divulging information because they lack legal work authorization or wish to avoid income reporting to limit taxes or maintain government assistance payments (Burkhart 2011; Hembram and Hoover 2008).

\section{TEMPORAL VARIABILITY}

The existing year-to-year tracking of NTFP markets suggests highly volatile and unpredictable supply and demand conditions (Chamberlain, Teets, and Kruger 2018; Frey, Chamberlain, and Prestemon 2018). Demand shifts due to changing societal norms and perceptions related to the safety and the desirability of "natural," "traditional," and "wild" products relative to alternatives. Media coverage of the purported benefits or negative effects of specific products also affects product demand. Supply is affected by ecological and social forces. Given the number of different products, each of which may have minor value, market players (e.g., harvesters, dealers, and other aggregators) often shift unexpectedly over time. For example, American ginseng harvest levels may be affected by local or regional unemployment levels (Bailey 1999; Frey, Chamberlain, and Prestemon 2018). Many NTFPs are only available for harvest for a short season. For example, ramp harvest is restricted to the few weeks between emergence of these spring ephemerals and canopy closure when ramp leaves senesce (Chamberlain et al. 2017). Also, major disturbances, such as wildfires, can have significant impacts on product quantity and quality. Some mushroom species, for example, fruit prolifically following wildfires (Pilz and Molina 2002). A final challenge related to temporal variability is that harvest rates may be unsustainable, so valuation of annual harvests may overstate the true ESV.

\section{GEOGRAPHIC VARIABILITY}

Provisioning of NTFPs is extremely variable across the forested landscape. Many NTFP species have very specific habitat requirements and are restricted to a single forest type. This specificity makes it challenging at best to apply valuation results across a forest landscape or from one site to another. Thus, if data on total harvest quantity comes from an off-forest aggregator, accurately attributing the harvests among various forest types in a county, state, or other regional level can be difficult. 


\section{Past Valuation Studies in the United States}

Few studies fit the paradigm of NTFP provisioning ES valuation. Among those using the NPV framework (equations 6-8) for NTFPs are those for wild mushrooms in the Pacific Northwest, which assume joint production of mushrooms and timber (Alexander et al. 2002; Pilz et al. 1998; Pilz et al. 1999). A particular challenge in this system has been estimating harvest, transaction, and processing costs $(H C+T C+P C$ in Equations 3-6). These include time scouting and traveling to harvest sites, harvesting, cleaning, and selling the product (Love, Jones, and Liegel 1998). To resolve this challenge, the authors assumed costs either to be a fixed percentage of the sale price or a range of estimates (Alexander et al. 2002; Pilz et al. 1998; Pilz et al. 1999). Depending on species, site, and assumptions about harvest costs, management, and productivity, estimated SEVs for mushrooms have ranged widely, from $\$ 17 /$ ha to $\$ 2,478 /$ ha (Alexander et al. 2002 ) at a $4 \%$ discount rate. In some cases, timber value was 10 to 100 times greater than mushroom value, while in other analyses, where timber values were low and mushroom values high, mushroom value equaled or exceeded timber value (Alexander et al. 2002; Pilz et al. 1999).

Forest farming incurs establishment and management costs $(E C+M C$ in equations 5-6). Burkhart and Jacobson (2009) estimated NPVs for forest farming of medicinal plants in the eastern United States and, with the exception of American ginseng, found them to be unprofitable. Determining an appropriate hourly cost for labor (wage rate) and a discount rate, as well as projecting product prices (which can be volatile) into the future, proved particularly challenging. Wage rate was estimated using an opportunity cost of $\$ 13 / \mathrm{hr}$, based on average wages for comparable types of work. A range of possible values was used for discount rate and product price.

\section{Getting Started}

\section{Define the geographic area}

NTFPs are harvested from most forest types across every region of the United States. Defining geographic boundaries and setting priorities as to products for estimating ESV are essential first steps (Chamberlain et al. 2017). Some forest types are more productive and thus warrant higher priority for ES valuation. For example, Appalachian hardwood forests have a high diversity of plants harvested for food and medicine, supplying large quantities of raw materials to industry. These forests span most eastern states, and estimating ESVs for the entire region is probably unrealistic. A better approach may be to focus on a particular state, forest type, or forested area. With more geographic specificity, it is more feasible to identify and evaluate sites known as sources of NTFPs (e.g., a well-known ramp or blueberry patch). 
Recognize forest type, ownership, and accessibility

Within geographic areas of interest, understanding forest types, the habitat requirements of the NTFP, and factors related to harvester access is critical. Valuation efforts should also consider the resource base as it interacts with changing ownership and management (Chamberlain et al. 2017), which may affect NTFP availability and ESVs. For example, if the availability of NTFPs on public forests decreases due to increased regulation, demand for NTFPs from private lands might increase, thus increasing ESVs on those lands. The relative importance of land ownership type varies across the United States, as western states have more public lands and eastern states more private lands. Conversely, as private forest habitats are impacted by land use change (e.g., mountain top removal, timber cutting, residential development), the ESV from other ownerships will be affected.

\section{Identify NTFPs for ES valuation}

Deciding which NTFP ESV to estimate is a crucial step. Institutions have limited resources for estimating the ESV and must therefore be selective. Product demand, ecological vulnerability, the status of the geographic area in the broader market, and cultural importance are key criteria (Chamberlain et al. 2017; Emery and Ginger 2014).

Priority NTFPs may be those well-known locally, nationally, and internationally, for which demand has increased, or those vulnerable to overharvesting or other threats. For example, it may be important in some states to estimate the ESV of wild American ginseng, given the current high demand in Asia and potential for overharvest (Ticktin 2004). The plant part (e.g., roots vs. berries) harvested may increase the potential for population declines from harvesting (Ticktin 2004), increasing priority for valuation.

Actual or potential harvest quantities in an institution's geographic area of interest/influence, relative to other regions, may indicate to decision-makers that valuation is worthwhile. This perception of importance may reflect actual market demand for the product(s), as well as standing stocks of species in the forest. If the standing stock is not known, estimation of the habitat for important NTFPs within the geographic area of interest may indicate relative potential for producing priority NTFPs. The uniqueness of a product and the market stature of a producer may factor into the decision as well. For example, the state of Florida is the major producer of saw palmetto, so it makes sense that this product would be a priority for that state, as opposed to Georgia, which has saw palmetto growing but is not a major producer. Conversely, Georgia is a major producer of pine straw, which makes this more of a priority for that state.

In setting priorities for product valuation, institutions may consider the economic and cultural importance of certain products to specific communities within a geographic area of interest. The perceived importance 
of a product to a region's economy, or to a specific segment of the region's population could be a justification for estimating the ESV of that product. For example, annual ramp festivals are important to the economy of western North Carolina. As such, estimating the provisioning ESV of this edible forest product may be warranted.

Understand method of production and sale; harvest site access; data availability

Before beginning the valuation process, recognize that the valuation method will depend on the method of production (typically wild-harvested or forest farmed) and sale, market chains, land ownership and access, size of the geographic area of interest, as well as data availability. For truly wildharvested products, no establishment or management costs exist-people forage for products in forests that are not managed for that product. For woods-grown, woods-cultivated, or wild-simulated products, relevant establishment and management costs must be considered. For products from managed natural populations, establishment costs may be negligible, but there could be management costs.

\section{Proposed Approaches}

\section{Production Costs}

We identified five main types of costs (establishment, management, harvest, processing, transaction) in equations (5-6). These costs may vary between harvesters and products. Establishment and management costs for forestfarmed products are typically associated with the landowner, given as costs per unit area. Woods-cultivated and woods-grown costs are higher than those of wild-simulated. Establishment costs are zero for managed natural populations, and both establishment and management costs fall to zero for wild-harvested products. Harvesting, processing, and transaction costs are associated with the harvester, and are given as costs per unit of product sold.

These categories provide a broad guide. A full accounting of relevant costs is needed to allocate expenses appropriately. The first step in estimating landowner and harvester costs is to identify and describe those costs. Understanding the actual processes, activities, and timing of the costs is critical (Cubbage et al. 2015). Magnitude of inputs for each activity can then be estimated, including hours of labor, quantities of supplies, services contracted, and equipment used. Finally, a price for each input must be determined to estimate the full cost.

Many commercial harvesters and landowners are self-employed and do not pay themselves per hour worked, and may also employ unpaid family labor. These producers may not consider their time to be a "cost" in the financial sense. However, including this economic cost is essential when estimating a 
provisioning ESV. Human labor represents a cost distinct from the ecosystem input.

Permit or contract fees for access to the resource are not among the costs in equation (5), because permits represent a simple transfer from harvester to the landowner rather than an economic cost of production. In some instances, this transfer itself could be an estimate of the ESV. For example, if the permit fee or contract price to access and extract the product are set in a competitive marketplace, such as when private landowners sell the right to access and harvest saw palmetto or pine straw on their land, the price may represent the full quasi-rent (equation 2) or an estimate of the costs of establishment and management. On public lands, federal agencies may base permit fees on an estimate of the ESV per unit of product harvested (Smith, Crone, and Alexander 2010), ${ }^{3}$ or the permit fee may offer a lower bound for total ESV.

\section{Harvest Quantity}

To estimate the provisioning ESV of NTFPs requires that the volume harvested per unit area of habitat be determined. In general, this is done by (1) estimating standing stock volume of product in the forest, or (2) estimating rate of harvest (i.e., flow) from a defined forest area. Standing stock measures the potential for future harvests. However, estimating the ESV of standing stock is hypothetical by nature because harvesting a large volume of the standing inventory at once could impact market prices and the sustainability of the resource. Moreover, determining the standing stock of NTFPs is challenging, particularly for products harvested for their roots, as there are few methods (Chamberlain et al. 2013).

The most straightforward approach, and one generally favored by researchers, is to estimate the rate of harvest from a specific site in a forest. The flow approach quantifies the raw material removed from an area over a period and accounts for the volume that reaches market. The best data is collected at the location of harvest, although this requires being on-site during harvest or having a relationship with trusted harvesters who will report accurately. Permitted harvest amounts can be a starting point, recognizing that permit holders may harvest less than (or on occasion, more than) their permit allows. As noted previously, one challenge with the flow approach is that rates of harvest may be unsustainable.

The approach to estimating quantity produced will depend on the forest area defined. Ideally, a specific harvest site of fixed area has been identified where

\footnotetext{
3 The National Forest System of the U.S. Forest Service and the U.S. Bureau of Land Management make reasonable attempts to base permit fees on an appraisal of the value of the product (Smith, Crone, and Alexander 2010). While there are some differences (e.g., fees are set per unit of product rather than per unit land area, and appraisal involves inclusion of a "rollback factor"), the appraisal approach could be a starting point for ecosystem service valuation.
} 
the quantity removed can be closely tracked. If this is not the case, then precise characterization of the forest type and habitat for the species of interest must be determined. Variables such as soils, elevation, slope, and aspect may be used to quantify habitat quality (Schmidt et al. 2019). The analysis should also include factors related to human access, such as trails, roads, and proximity to harvester residences. The more precisely the site can be described, the more accurate the estimation of the area of potential forest habitat for a particular NTFP or suite of products. On-the-ground verification can further improve the accuracy of estimations.

\section{Price}

As mentioned, price of NTFPs at the location of harvest will lead to the most accurate ESV estimate. It is possible that sales occur at different places along the market chain, with some enterprises buying only from harvesters and others buying from harvesters and other dealers (Kruger 2018). This can bias data, as it opens opportunities for double-counting harvest volumes. The farther along the market chain that price is collected, the more opportunities for inaccuracies are present due to additional steps of value adding. Realistically, price data are collected at the first point of sale, when the harvester sells the product to a dealer. This first point of sale, though, includes value adding through harvesting, cleaning, and transport.

\section{Potential Data Sources}

\section{Existing Sources}

Estimating production costs requires understanding of production methods, activities, and inputs, which to our knowledge are not tracked by any data service. Past research that includes estimates of production costs has elicited this information from expert knowledge, interviews with harvesters, or monitoring of forest farmer activities (e.g., Burkhart and Jacobson 2009; Davis and Persons 2014; Huyler 2000), and cooperative extension services sometimes produce "enterprise budgets" that provide a valuable reference point (e.g., Frey 2014). These offer cost estimates but are generally neither updated nor replicated at multiple geographic locations.

Once activities and inputs are known, a dollar value must be placed on each. The U.S. Bureau of Labor Statistics provides data on average wages by occupation, which can be used to find an appropriate opportunity cost of time for a typical harvester by geographic area (Bureau of Labor Statistics 2019). The Internal Revenue Service provides standard rates that can be used to estimate travel costs from the forest to the first point of sale.

Few sources provide data on the quantity of NTFPs harvested. The main sources of harvest volumes from federal forest lands are the USDA Forest 
Service's "cut-and-sold" reports, and similar reports from the Bureau of Land Management (Chamberlain, Teets, and Kruger 2018). These reports record permitted harvest volumes but not necessarily actual harvest volumes. Data reported at the forest level may be tracked to the district level but not disaggregated by habitat type. Thus, estimates of habitat area are needed to complement harvest data from reports. Through the USDA Forest Service's Forest Inventory and Analysis program, tree data is available from which the inventory of some NTFPs can be estimated. For example, trees harvested for bark are inventoried, and this data can be used to estimate the volume of bark harvested across the range of the species (Kauffman, Prisley, and Chamberlain 2015). The USDA Forest Service's National Woodland Owners Survey provides data on the proportion of private landowners who report the collection of NTFPs on their property but does not give species, commercial harvest volume, or price (Butler et al. 2016a, b).

Other federal and state agencies collect data on specific NTFPs. The National Agricultural Statistics Service (NASS) collects information on production of maple syrup, blueberries, and other well-known commodities, and these data may be used to estimate harvest volumes for states or regions (e.g., NASS 2018). The U.S. Fish and Wildlife Service, the federal authority for implementation of the Convention on International Trade of Endangered Species of Wild Flora and Fauna (CITES) that regulates American ginseng exports, is the repository of data on harvests reported at the state and county level. Some states allow harvesting on their forest lands and may have harvest permit information for some of the more common NTFPs (Frey and Chamberlain 2016). Georgia, for example, provides data on pine straw production through the farm gate value reports (e.g., Wolfe and Stubbs 2013, 2015).

Trade associations, such as the American Herbal Products Association (AHPA), collect information on harvest volume and price for specific products (e.g., Dentali and Zimmermann 2012). University, government, and independent research programs from time to time have tracked input cost, harvest volume, and price for NTFPs (e.g., Alexander et al. 2002; Davis and Persons 2014; Greenfield and Davis 2003; Huyler 2000; Kruger 2018; Pilz et al. 1998; Schlosser and Blatner 1995), typically relying on interviews with dealers and harvesters over limited periods of time.

\section{Surveys and Interviews}

Because existing sources of data related to production costs, harvest quantity, and price of NTFPs are generally lacking, it is often necessary to interview market players. The closer the data source is to the point of harvest, the greater the precision of the data. As those closest to the ES, harvesters are the preferred sources of information. The most statistically defensible approach is to randomly sample as large a subpopulation from the full population of harvesters as possible. Permits on public lands may be a 
source of information about harvesters, who can then be sampled for a survey. Starbuck et al. (2004), for example, compiled the names and addresses of all holders of recreational use special forest product harvesting permits from two National Forest districts in 1996 and conducted a mail survey of a sample of this population to estimate consumer surplus based on the travel cost method of non-market valuation. A similar approach could be used to contact harvesters for information related to market-oriented uses and to elicit information on production cost, harvest quantity, and price.

Often there is no list of harvesters, so random sampling is impossible. In this case, using expert knowledge to identify key groups of individuals and selecting a robust number from each stratum may be the best option. Failing a stratified sampling approach, a chain-referral approach may be used until saturation of the population or a substantial sample has been reached (Chamberlain et al. 2017).

In certain instances, reaching harvesters is not possible, and the first point along the market chain when the products enter the formal market may be the most feasible point to sample buyers. In the case of medicinal plants in the eastern United States, the list of registered ginseng buyers has proved an excellent source for identifying buyers of other medicinal plants (Kruger 2018), but it covers only 19 states.

A survey of wholesale firms in a specific segment of the industry may provide insights into ways to access harvesters. A snowball sample of market participants will help to identify the majority of firms. A stratified sample of known market segments (e.g., wholesale distributors of food or floral products) may be possible by examining databases available through government agencies.

\section{Case Studies}

The case studies here represent examples for which certain data are available. For some parameters, we supplemented with estimates by the authors. The purpose of these exercises is to provide the reader with a sense of workflow and the types of data required, not to provide values for decision-making directly, as much more precise information would be needed.

\section{Saw palmetto}

Saw palmetto, typically found in the understory of pine forests, is endemic to the Coastal Plain from South Carolina to Louisiana. The berries of the saw palmetto are used for medicinal purposes with an estimated average of approximately 8 million $\mathrm{kg} / \mathrm{yr}$ (18 million $\mathrm{lbs} / \mathrm{yr}$ ) of fresh berries harvestedalmost exclusively from Florida (Dentali and Zimmermann 2012). 'Independent' harvesters were paid $\$ 0.22-0.24 / \mathrm{kg}(\$ 0.10-0.11 / \mathrm{lb})$ of fresh berries (Carrington et al. 2000). Mitchell (2014) recorded prices paid to harvesters ranging from $\$ 0.22-2.20 / \mathrm{kg}(\$ 0.10-\$ 1.00 / \mathrm{lb})$, noting that on 
average harvesters were paid $\$ 1.10 / \mathrm{kg}(\$ 0.50 / \mathrm{lb})$ of fresh berries. Landowners who hired crews to harvest received $\$ 0.44-0.46 / \mathrm{kg}(\$ 0.20-0.21 / \mathrm{lb})$ of fresh berries, and paid harvesters about $\$ 0.15 / \mathrm{kg}(\$ 0.07 / \mathrm{lb})$ (Carrington et al. 2000). The price of harvester labor is clearly dynamic, and, although challenging, accurately estimating labor costs requires the active monitoring of buying stations during the harvest season and direct communication with harvesters to determine how much they get paid.

However, the saw palmetto market is structured such that, in many cases, a harvest contractor will pay a landowner directly, in a competitive marketplace, per unit area per year for the right to harvest saw palmetto berries from their forest. In this instance, the value of the contract between the harvester and landowner already has factored out the harvester's costs, and if the landowner has not invested any resources in establishing or managing the saw palmetto in the forest, the contract value can be considered equivalent to the quasi-rent or ESV at the margin. Carrington et al. (2000) reported harvest contract values ranging from $\$ 38-77 / \mathrm{ha} / \mathrm{yr}$ (\$15-31/ac/yr), which would be the EAI and translates to an SEV of $\$ 760$ $\$ 1,540$ per hectare $(\$ 308-625 / \mathrm{ac})$ at a $5 \%$ discount rate (equations $2,6-8)$.

\section{American ginseng}

American ginseng is an understory plant found in eastern hardwood forests. The roots are highly valued, particularly in East Asian cultures, for a variety of medicinal purposes. Because of a long history of widespread (destructive) harvest of roots, American ginseng is a species of conservation concern and listed under CITES, and therefore harvest for export is tracked by the U.S. Fish and Wildlife Service (2015). Annually, an average of approximately $27,000 \mathrm{~kg}$ dry $(60,000 \mathrm{lbs}$ dry) of wild American ginseng are harvested from eastern forests for export (Chamberlain, Prisley, and McGuffin 2013; Frey, Chamberlain, and Prestemon 2018). ${ }^{4}$

Approximately $0.5 \%$ of the American ginseng harvest comes from National Forests in Georgia, Kentucky, North Carolina, and Tennessee..$^{5}$ Let us consider the Pisgah and Nantahala National Forests in North Carolina (NFSNC) as a case study. ${ }^{6}$ The NFSNC include 422,670 ha $(1,044,000$ acres) in the southern Appalachian Mountains. The USDA Forest Service cut and sold reports indicate that from 2009 to 2012, an average of $260 \mathrm{~kg} / \mathrm{yr}$ (573 lbs/yr) of

\footnotetext{
4 An approximate equivalency is $3 \mathrm{~kg}$ green $=1 \mathrm{~kg}$ dry (personal communication: James Hamilton, NC Cooperative Extension Service).

5 Percentage is authors' estimate based on an annual average of National Forest permitted harvest of $404 \mathrm{~kg}$ green (Chamberlain et al. 2017) divided by total U.S. harvest of 81,000 kg green.

6 The NFSNC include the Pisgah, Nantahala, Uwharrie, and Croatan National Forests; however, ginseng harvest is permitted only on the first two. We use the acronym NFSNC because it is used for administrative purposes and permit reporting, but for practical purposes with regard to permitted ginseng harvest, we only include information related to the Pisgah and Nantahala.
} 
Table 1. First approximation of average value estimates of American ginseng on the National Forests in North Carolina, 2009-2012.

\begin{tabular}{lccccc}
\hline & $\begin{array}{c}\text { Midpoint } \\
\text { price at } \\
\text { first point } \\
\text { of sale } \\
\text { (\$/kg } \\
\text { green) }\end{array}$ & $\begin{array}{c}\text { Assumed } \\
\text { cost of } \\
\text { harvesting, } \\
\text { processing, } \\
\text { and } \\
\text { transaction } \\
\text { (\$/kg green) }\end{array}$ & $\begin{array}{c}\text { Quantity } \\
\text { permitted } \\
\text { for harvest } \\
\text { (kg green) }\end{array}$ & $\begin{array}{c}\text { Establishment } \\
\text { and } \\
\text { management } \\
\text { costs } \mathbf{~} \text { (\$/ha) }\end{array}$ & $\begin{array}{c}\text { American } \\
\text { ginseng } \\
\text { estimated } \\
\text { annual } \\
\text { value for } \\
\text { NFSNC }\end{array}$ \\
\hline 2009 & $\$ 349$ & $\$ 80$ & 289 & $\$ 0$ & $\$ 77,741$ \\
2010 & $\$ 533$ & $\$ 80$ & 189 & $\$ 0$ & $\$ 85,617$ \\
2011 & $\$ 393$ & $\$ 80$ & 208 & $\$ 0$ & $\$ 65,104$ \\
2012 & $\$ 606$ & $\$ 80$ & 284 & $\$ 0$ & $\$ 149,384$ \\
Average & $\mathbf{\$ 4 7 0}$ & $\mathbf{\$ 8 0}$ & $\mathbf{2 4 3}$ & $\mathbf{\$ 0}$ & $\mathbf{\$ 9 4 , 4 6 2}$ \\
\hline
\end{tabular}

a Source: Adapted from Davis and Persons (2014).

${ }^{\mathrm{b}}$ American ginseng on the NFSNC is assumed to be wild-harvested, so there is no establishment or management cost. We include the column as a reminder to the reader.

green American ginseng root were permitted for harvest from NFSNC (Table 1) (Chamberlain et al. 2017).

Davis and Persons (2014) interviewed ginseng buyers (the first point of sale after harvest) throughout the eastern United States each year between 1982 and 2012 during harvest season and reported a range of prices. From 2009 to 2012 , the average midpoint price was $\$ 1,411 / \mathrm{kg}$ dry $(\$ 640 / \mathrm{lb}$ dry, Table 1), translating to approximately $\$ 470 / \mathrm{kg}$ green ( $\$ 213 / \mathrm{lb}$ green).

As a first approximation, we estimated approximate average ESVs for ginseng in the NFSNC. We assumed that National Forest permits were equal to harvests, that they were entirely from unmanaged populations where no resources were invested in either establishment or management, that the equipment and supplies used by harvesters were of negligible cost, and that the labor of harvesting, transacting, and processing roots was the only non-negligible production input and equaled $8 \mathrm{hrs} / \mathrm{kg}$ green at an opportunity cost of $\$ 10 / \mathrm{hr}$.

We used equation (5) to estimate an annual average value for American ginseng on the NFSNC (Table 1). Because the price and quantity could be correlated either positively or negatively, we did not simply multiply the annual average price minus cost by the annual average quantity harvested. Rather, we calculated the ESV as an average $E A I$ of $\$ 94,462 / y r$, or an $S E V$ of $\$ 1,889,230$ at a $5 \%$ discount rate, translating to $\$ 4.47 /$ ha $(\$ 1.81 / \mathrm{ac}$ ) or $\$ 0.22 / \mathrm{ha} / \mathrm{yr}$ ( $\$ 0.09 / \mathrm{ac} / \mathrm{yr}$ ).

To be actionable for forest management decision-making purposes, more spatially explicit information on ginseng occurrence and harvest size needs to be included in the valuation model. Thus, to translate estimates of average value per ha into estimated marginal values per ha, we incorporated proxies for spatial variability in harvestable quantity and for harvest costs. We assumed 
that the probability of ginseng presence was determined by habitat factors, including parent material, landform, climate, and soil taxonomy, as outlined in Schmidt et al. (2019). We used a raster (9 ha [22 acre] pixel resolution) of probabilities of ginseng occurrence generated by the species distribution model (SDM) developed by Schmidt et al. (2019). After clipping the SDM raster to the boundary of the NFSNC, we binned probabilities of finding ginseng on a given pixel as 0.1 (23,695 pixels), 0.5 (18,335 pixels), and 0.9 (3,089 pixels).

Although actual presence and total quantity of ginseng harvestable at the pixel are unverified, the purpose of this exercise was to better understand the distribution of potential ESV within the NFSNC. First, using a random number generator and the probabilities just given, we randomly assigned ginseng presence or absence to each pixel. This leads to an average of 14,317 pixels with ginseng presence out of 45,149 total pixels, or $32 \%$. Second, for each of the resulting pixels with ginseng presence, we then generated a random harvestable quantity from a beta distribution with mean 0.10 green $\mathrm{kg}$ and maximum of $0.60 \mathrm{~kg}$ per 9-ha pixel. ${ }^{7,8}$ Third, we randomly assigned detection by harvesters each year at each presence pixel with probability of $0.5^{9}$ and assumed that at each pixel where harvest occurred, $100 \%$ of the harvestable quantity was removed.

We modeled transaction and harvest costs as functions of distance to road, slope, and amount of ginseng present. Using the SDM raster as a template, we converted a shapefile of roads ${ }^{10}$ to a raster. Then, using the "distance" command in the "raster" package (Hijmans 2019) in R (R Development Core Team 2005), we converted the road raster into a raster of distance (m) from road. To create a raster of slope (degrees) at the same resolution as the SDM data for the National Forest, we downloaded high-resolution elevation data (0.0225 ha) via the "elavatr" package (Hollister and Shah 2017) in R, and derived slope using the "slopeAspect" command. We estimated transaction and harvest costs for each pixel as

$$
\begin{gathered}
T C_{i}=\text { opp } \cdot\left(\left(\frac{\text { dist }_{i}}{s p}\right) \cdot\left(1+s_{i}\right)\right)+f c \\
H C_{i}=o p p \cdot\left(h r \cdot Q_{i} \cdot\left(1+s_{i}\right)\right)
\end{gathered}
$$

where

\footnotetext{
7 With beta distribution parameters $\alpha=2, \beta=10$, minimum $=0$, maximum $=0.6$.

8 Estimate of the amount of ginseng likely available at various sites, based on consultation with experts (personal communication, James Hamilton, NC Cooperative Extension Service), relevant literature (McGraw, Souther, and Lubbers 2010), and that multiple ginseng populations likely exist on many 9-ha areas where ginseng is present.

9 Based on McGraw, Souther, and Lubbers (2010).

10 Available from the North Carolina Department of Transportation https://connect.ncdot.gov/ resources/gis/Pages/GIS-Data-Layers.aspx.
} 
opp is the opportunity cost of time, set to $\$ 10 / \mathrm{hr}$,

dist $_{i}$ is distance from the pixel to road (m),

$s p$ is the speed at which a harvester can traverse relatively flat forested terrain, set to 5,000 $\mathrm{m} / \mathrm{hr}$,

$S_{i}$ is the speed adjustment factor based on slope, equal to 0 for slopes $<20^{\circ}, 0.5$ for slopes $20-30^{\circ}$ and 1 for slopes $>30^{\circ}$,

$f c$ are fixed transaction costs, set to $\$ 15$,

$\mathrm{hr}$ is the rate of harvest, set to $2 \mathrm{hrs} / \mathrm{kg}$.

This simulation yielded an estimate of $425 \mathrm{~kg} / \mathrm{yr}$ of green ginseng harvested with a total ESV of $\$ 88,978 / y$, mean ESV across presence pixels of approximately AEI of $\$ 1.90 / \mathrm{ha} / \mathrm{yr}(\$ 0.77 / \mathrm{ac} / \mathrm{yr})$ or SEV of $\$ 38 / \mathrm{ha}(\$ 15 / \mathrm{ac})$, and maximum value of approximately AEI of $\$ 11.50 / \mathrm{ha} / \mathrm{yr}(\$ 4.65 / \mathrm{ac} / \mathrm{yr})$ or SEV of $\$ 230 /$ ha $(\$ 93 /$ ac).

These estimates are for the purpose of demonstration only and are highly uncertain. Although we do not estimate confidence intervals or quantify the level of uncertainty in the ESV estimates, additional research could surely improve these estimates. There are several sources of uncertainty in the underlying assumptions: (1) the estimated likelihood of ginseng presence based on ecological modeling, (2) the random assignment of harvestable quantity levels where ginseng was predicted to be present, (3) the likelihood of detection, (4) harvest costs, and (5) estimates of the first point of sale price, which were based on the best existing source (Davis and Persons 2014), and provided information on the range but not the distribution of existing prices. Research to improve these estimates would likely require detailed interviews with many harvesters and buyers to generate more precise estimates of harvest quantities, costs, and prices. Further, our spatial methods only indicate likelihoods, not certainties, so improving estimates for individual sites' field inventories would be needed.

\section{Conclusions}

NTFPs are valued throughout the United States for food, medicines, decorations, landscaping, and arts and crafts, and are important to the cultural traditions and livelihoods of many people. As such, NTFPs are among the many ES provided by forest ecosystems, and while sometimes assumed to be of lesser value than timber ES, this is not always the case (Alexander et al. 2002; Pilz et al. 1999). Here, we have outlined methods for valuation of the provisioning of marketbased NTFPs. Quantifying the ESV of market-based NTFPs can lead land managers to a better understanding of the effects of their decisions on local communities. Non-market values also are significant for NTFPs and remain an important parallel research topic. 
Estimating the provisioning ESV of forests for marketed NTFPs requires finding the residual value of the product-the value remaining after factoring out human labor and capital inputs. Such an approach is applicable at the marginal level, that is, for small changes in forest area or to an enterprise.

Determining these residual values is challenging, as very little information on cost of production, quantity harvested, or product price is readily available. Moreover, incorporating marginal changes requires data on differences in production at relatively small scales (e.g., individual harvest sites) and, potentially, differences in cost structure between harvesters. Estimating ESV involves collection of data from institutional sources, expert knowledge, and surveys of harvesters and dealers. Although estimating the provisioning ESV for NTFPs is fraught with challenges, the benefits of addressing the challenges and undertaking valuation is needed to highlight the importance of these products.

Due to the challenges with data, difficulties eliciting information from market players, high levels of temporal and spatial variability, and perceptions of minor economic importance, ES valuation related to NTFPs is underdeveloped in comparison with other ESs such as provisioning of timber or regulation of air and water. To further the discussion and science of ESVs of NTFPs, we presented case studies of saw palmetto in Florida and American ginseng in the NFSNC to illustrate valuation process and challenges. These case studies demonstrate the types of data needed, potential workflows, and the high degree of spatial variability of ESVs over the landscape. Future work is needed to better understand presence and absence of NTFPs across the landscape; harvestable quantities, including intertemporal dynamics; and harvester costs, including the value of ecological knowledge.

\section{Acknowledgements}

The authors would like to thank Drs. Marla Emery and David Simpson for their valuable comments on a draft of this manuscript.

\section{Disclaimer}

The findings and conclusions in this publication are those of the authors and should not be construed to represent any official USDA or U.S. Government determination or policy.

\section{Financial Disclosure}

This research received no specific grant from any funding agency, commercial, or not-for-profit sectors. 


\section{References}

Alexander, S.J., R.J. McLain, and K.A. Blatner. 2001. "Socio-economic Research on Non-Timber Forest Products in the Pacific Northwest." Journal of Sustainable Forestry 13(3-4): 95-103.

Alexander, S.J., S.N. Oswalt, and M.R. Emery. 2011. Nontimber Forest Products in the United States: Montreal Process Indicators as Measures of Current Conditions and Sustainability. Gen. Tech. Rep. PNW-GTR-851. Portland, OR: U.S. Department of Agriculture, Forest Service, Pacific Northwest Research Station. 36 p.

Alexander, S.J., D. Pilz, N.S. Weber, E. Brown, and V.A. Rockwell. 2002. "Mushrooms, Trees, and Money: Value Estimates of Commercial Mushrooms and Timber in the Pacific Northwest." Environmental Management 30(1): 129-141.

Bailey, B. 1999. “Social and Economic Impacts of Wild Harvested Products.” PhD Dissertation, West Virginia University.

Ballard, H.L., and L. Huntsinger. 2006. "Salal Harvester Local Ecological Knowledge, Harvest Practices and Understory Management on the Olympic Peninsula, Washington." Human Ecology 34(4): 529-547.

Baumflek, M. 2016. "Developing Standards for Sustainable Commercial Ramp Harvesting." Temperate Agroforester 22(3).

Belcher, B M. 2003. "What Isn't an NTFP?" International Forestry Review 5(2): 161-168.

Bulte, E., and S. Engel. 2006. "Conservation of Tropical Forests: Addressing Market Failure." In Economic development and environmental sustainability: new policy options, edited by R. López and M.A. Toman, 412-453. Oxford University Press.

Bureau of Labor Statistics. 2019. "Overview of BLS Wage Data by Area and Occupation." U.S. Department of Labor, Bureau of Labor Statistics, accessed March 11. http://www.bls.gov/ bls/blswage.htm.

Burkhart, E.P. 2011. "Conservation Through Cultivation: Economic, Socio-Political and Ecological Considerations Regarding the Adoption of Ginseng Forest Farming in Pennsylvania." PhD Dissertation, The Pennsylvania State University.

Burkhart, E.P., and M.G. Jacobson. 2009. "Transitioning from Wild Collection to forest Cultivation of Indigenous Medicinal Forest Plants in Eastern North America is Constrained by Lack of Profitability." Agroforestry Systems 76(2): 437-453.

Butler, B.J. 2008. Family Forest Owners of the United States, 2006. Gen. Tech. Rep. NRS-27. Newtown Square, PA: U.S. Department of Agriculture, Forest Service, Northern Research Station. 72 p.

Butler, B.J., J.H. Hewes, B.J. Dickinson, K. Andrejczyk, S.M. Butler, and M. Markowski-Lindsay. 2016a. "Family Forest Ownerships of the United States, 2013: Findings from the USDA Forest Service's National Woodland Owner Survey." Journal of Forestry 114(6): 638-647.

— 2016b. USDA Forest Service National Woodland Owner Survey: national, Regional, and State Statistics for Family Forest and Woodland Ownerships with 10+ Acres, 2011-2013. Res. Bull. NRS-99. Newtown Square, PA: U.S. Department of Agriculture, Forest Service, Northern Research Station. 39 p.

Carrington, M.E., J.J. Mullahey, G. Krewer, B. Boland, and J. Affolter. 2000. "Saw Palmetto (Serenoa Repens): An Emerging Forest Resource in the Southeastern United States." Southern Journal of Applied Forestry 24(3): 129-134.

Chamberlain, J.L., R. Bush, and A.L. Hammett. 1998. "Non-Timber Forest Products: The Other Forest Products." Forest Products Journal 48(10): 10-19.

Chamberlain, J.L., J. Davis, M. Duguid, D. Ellum, M. Farrell, J.B. Friday, D. Fuller, S. Kruger, H. Marcano-Vega, J-A. McCoy, D. Page, S. Prisley, J. Young, and J.C. Zasada. 2018. "Nontimber Forest Products and Production." In Assessment of Nontimber Forest Products in the United States under Changing Conditions, Gen. Tech Rep. SRS-232, edited by J.L. Chamberlain, M.R. Emery and T. Patel-Weynand, 9-57. Asheville, NC: U.S. Department of Agriculture, Forest Service, Southern Research Station. 
Chamberlain, J.L., M.R. Emery, and T. Patel-Weynand, eds. 2018. Assessment of Nontimber Forest Products in the United States under Changing Conditions. Gen. Tech. Rep. SRS232. Asheville, NC: U.S. Department of Agriculture, Forest Service, Southern Research Station.

Chamberlain, J.L., G.E. Frey, C.D. Ingram, M.G. Jacobson, and C.M.S. Downes. 2017. "Forest Ecosystem Services: Provisioning Of Non-Timber Forest Products." In Trees at Work: Economic Accounting for Forest Ecosystem Services in the U.S. South, Gen. Tech. Rep. $S R S-226$, edited by E.O. Sills, S.E. Moore, F.W. Cubbage, K.D. McCarter, T.P. Holmes, and D.E. Mercer, 65-93. Asheville, NC: U.S. Department of Agriculture Forest Service, Southern Research Station.

Chamberlain, J.L., D Mitchell, T Brigham, T Hobby, L Zabek, and J Davis. 2009. "Forest Farming Practices." In North American Agroforestry: An Integrated Science and Practice, $2^{\text {nd }}$ edition, edited by H.E. Garrett, 219-256. Madison, WI: American Society of Agronomy.

Chamberlain, J.L., G. Ness, C.J. Small, S.J. Bonner, and E.B. Hiebert. 2013. "Modeling BelowGround Biomass to Improve Sustainable Management of Actaea Racemosa, a Globally Important Medicinal Forest Product." Forest Ecology and Management 293: 1-8.

Chamberlain, J.L., S. Prisley, and M. McGuffin. 2013. "Understanding the Relationships between American Ginseng Harvest and Hardwood Forests Inventory and Timber Harvest to Improve Co-Management of the Forests of Eastern United States." Journal of Sustainable Forestry 32(6): 605-624.

Chamberlain, J.L., A. Teets, and S. Kruger. 2018. Nontimber Forest Products in the United States: An Analysis for the 2015 National Sustainable Forest Report. e-Gen. Tech. Rep. SRS-229. Asheville, NC: U.S. Department of Agriculture, Forest Service, Southern Research Station. 36 p.

Coglan, L., and S. Pascoe. 1999. "Separating Resource Rents from Intra-Marginal Rents in Fisheries' Economic Survey Data." Agricultural and Resource Economics Review 28(2): 219-228.

Cordell, H.K., C.J. Betz, S.H. Mou, and D.D. Gormanson. 2012. Outdoor Recreation in the Northern United States. Gen. Tech. Rep. NRS-100. Newtown Square, PA: U.S. Department of Agriculture, Forest Service, Northern Research Station. 74 p.

Cordell, H.K., and M.A. Tarrant. 2002. "Forest-Based Outdoor Recreation.” In Southern Forest Resource Assessment, Gen. Tech. Rep. SRS-53, edited by D.N. Wear and J.G. Greis, 269-282. Asheville, NC: U.S. Department of Agriculture, Forest Service, Southern Research Station.

Cubbage, F.W., R.R. Davis, G.E. Frey, D.C. Behr, and E.O. Sills. 2015. "Financial and Economic Evaluation Guidelines for International Forestry Projects." In Tropical forestry handbook, edited by L. Pancel and M. Kohl. Berlin: Springer Berlin Heidelberg.

Cullina, W. 2000. The New England Wild Flower Society Guide to Growing and Propagating Wildflowers of the United States and Canada: Houghton Mifflin Harcourt.

Davis, J.M., and W.S. Persons. 2014. Growing and Marketing Ginseng, Goldenseal and Other Woodland Medicinals. 2nd edition. British Columbia, Canada: New Society Publishers.

Dentali, S., and M. Zimmermann. 2012. Tonnage Surveys of Select North American WildHarvested Plants, 2006-2010. Silver Spring, MD: American Herbal Products Association.

Emery, M.R., and C. Ginger. 2014. Special Forest Products on the Green Mountain and Finger Lakes National Forests: A Research-Based Approach to Management. Gen. Tech Rep. NRS131. Newtown Square, PA: U.S. Department of Agriculture, Forest Service, Northern Research Station. 51 p.

Emery, M.R., C. Ginger, S. Newman, and M.R.B. Giammusso. 2003. Special Forest Products in Context: Gatherers and Gathering in the Eastern United States. Gen. Tech. Rep. NE-306. Newtown Square, PA: U.S. Department of Agriculture, Forest Service, Northeastern Research Station. 59 p.

Farrell, M.L., and B.F. Chabot. 2012. "Assessing the Growth Potential and Economic Impact of the US Maple Syrup Industry." Journal of Agriculture, Food Systems, and Community Development 2(2): 11-27. 
Fish and Wildlife Service. 2015. American Ginseng. U.S. Department of the Interior, Fish and Wildlife Service, accessed April 9, 2015. http://www.fws.gov/international/plants/ american-ginseng.html.

Flaaten, 0. 2011. Fisheries Economics and Management. Tromsø, Norway: University of Troms $\varnothing$, Norwegian College of Fishery Science. 172 p.

Freeman, A.M. III. 2003. The Measurement of Environmental and Resource Values: Theory and Methods. 2nd ed. Washington, DC: RFF Press.

Frey, G.E. 2014. The Basics of Hardwood-Log Shiitake Mushroom Production and Marketing. Publication ANR-102P. Blacksburg, VA: Virginia Cooperative Extension. 9 p.

Frey, G.E., K.A. Blatner, M.G. Jacobson, C.M.S. Downes, E.O. Sills, D.E. Mercer, S.J. Alexander, J.L. Chamberlain, M.A. Gold, L.D. Godsey, M.R. Emery, A.W. Coffin, R.J. Barlow, and L. Lohr. 2018. "Economics of Nontimber Forest Products." In Assessment of Nontimber Forest Products in the United States under Changing Conditions, Gen. Tech Rep. SRS-232, edited by J.L. Chamberlain, M.R. Emery and T. Patel-Weynand, 119-149. Asheville, NC: U.S. Department of Agriculture, Forest Service, Southern Research Station.

Frey, G.E., and J.L. Chamberlain. 2016. "Collection of Nontimber Forest Products from State Forests in the US South." Journal of Forestry 114(2): 85-88. doi: 10.5849/jof.15-043.

Frey, G.E., J.L. Chamberlain, and J.P. Prestemon. 2018. "The Potential for a Backward-Bending Supply Curve of Non-Timber Forest Products: An Empirical Case Study of Wild American Ginseng Production." Forest Policy and Economics 97: 97-109.

Goldberg, C. 1996. "From Necessity, New Forest Industry Rises." New York Times, 24 March 1996.

Gordon, H.S. 1954. "The Economic Theory of a Common-Property Resource: The Fishery." Journal of Political Economy 62(2): 124-142.

Greenfield, J., and J.M. Davis. 2003. Collection to Commerce: Western North Carolina NonTimber Forest Products and Their Markets. Raleigh, NC: North Carolina State University.

Hembram, D., and W.L. Hoover. 2008. "Nontimber Forest Products in Daniel Boone National Forest Region-Economic Significance and Potential for Sustainability." In Proceedings of the 16th Central Hardwoods Forest Conference; 8-9 April 2008; West Lafayette, IN, Gen. Tech. Rep. NRS-P-24, edited by D.F. Jacobs and C.H. Michler, 148-156. Newtown Square, PA: U.S. Department of Agriculture, Forest Service, Northern Research Station.

Hijmans, R.J. 2019. "Raster: Geographic Data Analysis and Modeling." R package version 2.8-19.

Hollister, J.W., and T. Shah. 2017. "elevatr: Access Elevation Data from Various APIs." R package version 0.1.3.

Hummel, S., and F.K. Lake. 2015. "Forest Site Classification for Cultural Plant Harvest by Tribal Weavers Can Inform Management." Journal of Forestry 113(1): 30-39.

Huyler, Neil K. 2000. Cost of Maple Sap Production for Various Size Tubing Operations. Res. Pap. NE-712. Newtown Square, PA: U.S. Department of Agriculture, Forest Service, Northeastern Research Station. 6 p.

Jones, E.T., R.J. McLain, and K.A. Lynch. 2004. The Relationship between Nontimber Forest Product Management and Biodiversity in the United States. Washington, DC: National Commission on Science for Sustainable Forestry. 61 p.

Kauffman, J.S., S.P. Prisley, and J.L. Chamberlain. 2015. "Monitoring Nontimber Forest Products Using Forest Inventory Data: An Example with Slippery Elm Bark." Journal of Forestry 115(4): 292-299.

Kronenberg, J., and K. Hubacek. 2013. "Could Payments for Ecosystem Services Create an 'Ecosystem Service Curse'?" Ecology and Society 18(1): 10.

Kruger, S.D. 2018. "Measuring Medicinal Nontimber Forest Products Output in eastern Deciduous Forests." Ph.D. dissertation, Virginia Polytechnic Institute and State University.

Lake, F.K., M.R. Emery, M.J. Baumflek, K.S. Friday, K. Kamelamela, L. Kruger, N. Grewe, J. Gilbert, and N.J. Reo. 2018. "Cultural Dimensions of Nontimber Forest Products." In Assessment of Nontimber Forest Products in the United States under changing 
Conditions, Gen. Tech Rep. SRS-232, edited by J.L. Chamberlain, M.R. Emery and T. PatelWeynand, 84-99. Asheville, NC: U.S. Department of Agriculture, Forest Service, Southern Research Station.

Love, T., E. Jones, and L. Liegel. 1998. "Valuing the Temperate Rainforest: Wild Mushrooming on the Olympic Peninsula Biosphere Reserve." Ambio (Special Report No. 9): 16-25.

Markstrom, D.C., and D.M. Donnelly. 1988. "Christmas Tree Cutting: Demand and Value as Determined by the Travel Cost Method." Western Journal of Applied Forestry 3(3): 83-86.

McConnell, K.E., and N.E. Bockstael. 2005. "Valuing the Environment as a Factor of Production." In Handbook of environmental economics, edited by K.-G. Mäler and J.R. Vincent, 621-669. Elsevier, B.V.

McGraw, J.B., S. Souther, and A.E. Lubbers. 2010. "Rates of Harvest and Compliance with Regulations in Natural Populations of American Ginseng (Panax Quinquefolius L.)." Natural Areas Journal 30(2): 202-210.

McLain, R.J., S.J. Alexander, and E.T. Jones. 2008. Incorporating Understanding of Informal Economic Activity in Natural Resource and Economic Development Policy. Gen. Tech. Rep. PNW-GTR-755. Portland, OR: U.S. Department of Agriculture, Forest Service, Pacific Northwest Research Station. 53 p.

Millennium Ecosystem Assessment. 2005. Ecosystems and Human Well-Being: Synthesis. Washington, DC: Island Press.

Mitchell, C.M. 2014. “Contested Spaces: NTFPs, Livelihoods, and Conservation Planning." PhD Dissertation, Florida Atlantic University.

NASS. 2018. United States Maple Syrup Production. Washington, DC: U.S. Department of Agriculture, National Agricultural Statistics Service.

Pilz, D., F.D. Brodie, S.J. Alexander, and R. Molina. 1998. "Relative Value of Chanterelles and Timber as Commercial Forest Products." Ambio: 14-16.

Pilz, D., and R. Molina. 2002. "Commercial Harvests of Edible Mushrooms from the Forests of the Pacific Northwest United States: Issues, Management, and Monitoring for Sustainability." Forest Ecology and Management 155(1): 3-16.

Pilz, D., J. Smith, M.P. Amaranthus, S.J. Alexander, R. Molina, and D. Luoma. 1999. "Mushrooms and Timber - Managing Commercial Harvesting in the Oregon Cascades." Journal of Forestry 97(3): 4-11.

R Development Core Team. 2005. R: A language and Environment for Statistical Computing, Reference Index. Version 221 Vienna, Austria: R Foundation for Statistical Computing.

Robbins, P., M.R. Emery, and J.L. Rice. 2008. “Gathering in Thoreau's Backyard: Nontimber Forest Product Harvesting as Practice." Area 40(2): 265-277.

Schlosser, W.E., and K.A. Blatner. 1995. "The Wild Edible Mushroom Industry of Washington, Oregon and Idaho: a 1992 Survey." Journal of Forestry 93(3): 31-36.

Schmidt, J.P., J. Cruse-Sanders, J.L. Chamberlain, S. Ferreira, and J.A. Young. 2019. “Explaining Harvests of Wild-Harvested Herbaceous Plants: American Ginseng as a Case Study." Biological Conservation 231:139-149.

Sills, E.O., R D. Simpson, and D.E. Mercer. 2017. “Introduction.” In Trees at work: Economic Accounting for Forest Ecosystem Services in the U.S. South, Gen. Tech. Rep. SRS-226, edited by E.O. Sills, S.E. Moore, F.W. Cubbage, K.D. McCarter, T.P. Holmes, and D.E. Mercer, 1-7. Asheville, NC: U.S. Department of Agriculture Forest Service, Southern Research Station.

Smith, J., L.K. Crone, and S.J. Alexander. 2010. A U.S. Forest Service Special Forest Products Appraisal System: Background, Methods, and Assessment. Gen. Tech. Rep. PNW-GTR822. Portland, OR: U.S. Department of Agriculture, Forest Service, Pacific Northwest Research Station. 22 p.

Starbuck, C.M., S.J. Alexander, R.P. Berrens, and A.K. Bohara. 2004. "Valuing Special Forest Products Harvesting: A Two-Step Travel Cost Recreation Demand Analysis." Journal of Forest Economics 10(1): 37-53. 
Ticktin, T. 2004. "The Ecological Implications of Harvesting Non-Timber Forest Products." Journal of Applied Ecology 41(1): 11-21.

Watson, K., C.S. Christian, M.R. Emery, P.T. Hurley, R.J. McLain, and C. Wilmsen. 2018. "Social Dimensions of Nontimber Forest Products." In Assessment of Nontimber Forest Products in the United States under Changing Conditions, Gen. Tech Rep. SRS-232, edited by J.L. Chamberlain, M.R. Emery, and T. Patel-Weynand, 101-117. Asheville, NC: U.S. Department of Agriculture, Forest Service, Southern Research Station.

Wolfe, K., and K. Stubbs. 2013. 2012 Georgia Farm Gate Value Report. Athens, GA: University of Georgia, The Center for Agribusiness and Economic Development.

— 2015. 2014 Georgia Farm Gate Value Report. Athens, GA: University of Georgia, College of Agricultural and Environmental Sciences, Center for Agribusiness and Economic Development. 